Winter 2012

\title{
A Review of When Legal Orders Collide: The Role of Courts by Sabino Cassese
}

Kathleen Claussen

Permanent Court of Arbitration, kclaussen@pca-cpa.org

Follow this and additional works at: https://www.repository.law.indiana.edu/ijgls

Part of the Courts Commons, and the International Law Commons

\section{Recommended Citation}

Claussen, Kathleen (2012) "A Review of When Legal Orders Collide: The Role of Courts by Sabino Cassese," Indiana Journal of Global Legal Studies: Vol. 19 : Iss. 1 , Article 16.

Available at: https://www.repository.law.indiana.edu/ijgls/vol19/iss1/16

This Book Review is brought to you for free and open access by the Law School Journals at Digital Repository @ Maurer Law. It has been accepted for inclusion in Indiana Journal of Global Legal Studies by an authorized editor of Digital Repository @ Maurer Law. For more information, please contact rvaughan@indiana.edu.

\section{$\Psi$}

JEROME HALL LAW LIBRARY

INDIANA UNIVERSITY

Maurer School of Law
Blooming ton 


\title{
A Review of When Legal Orders Collide: The Role of Courts by Sabino Cassese
}

\author{
KATHLEEN CLAUSSSEN
}

The growth and interaction of legal orders beyond the state has precipitated considerable interest among scholars and practitioners. The resulting discussion both in the academy and in the upper reaches of government about the intersection of national legal orders with new areas of non-national law has led to various predictions about possible ramifications of this phenomenon. In recent years, the importance of these transnational questions has grown concurrently with the expansive creation and heightened activity of supranational and global organizations. ${ }^{1}$ Some have gone so far as to herald a new global law, and others have elaborated upon its contours. ${ }^{2}$ Sabino Cassese begins his latest book, When Legal Orders Collide: The Role of Courts, by tackling a fundamental question underlying these active dialogues: Who holds together the legal orders of the world? What follows is a captivating exploration of the place of quasi-judicial bodies in navigating and directing divergences across the legal orders.

As a judge on the Constitutional Court of Italy and a renowned scholar of Italian and global administrative law, Cassese brings to the book deep insight, shaped by his many years of experience. This latest work, a natural extension of Cassese's prolific portfolio, elaborates on the role of courts in bridging legal orders. In his prior works, Cassese examined ways in which supranational law operates in national legal systems through procedural principles, as well as through the

\footnotetext{
* Assistant Legal Counsel, Permanent Court of Arbitration. Opinions expressed herein are those of the author alone.

1. See, e.g., Challenging ACts of International Organizations in National COURTS (August Reinisch ed., 2010) (describing examples of international and supranational organizations engaged in litigation); THE RULES, PRACTICE, AND JURISPRUDENCE OF INTERNATIONAL COURTS AND TRIBUNALS (Chiara Giorgetti ed., 2011) (illustrating the growth among world courts' and quasi-judicial bodies' dockets in recent years); MARGaret P. KARnS \& Karen A. MingST, INTERNATIONAL ORganizations: THE POLITICS AND PROCESSES OF GLOBAL CHANGE (2d ed. 2009) (capturing the wide variety of organizations and their diverse spheres of activity).

2. See generally, e.g., RAFAEL DOMingo, THE NEW GLOBAL LAW (2010); GLOBAL LAW WITHOUT A STATE (Gunther Teubner ed., 2003).
}

Indiana Journal of Global Legal Studies Vol. 19 \#1 (Winter 2012)

(C) Indiana University Maurer School of Law 
institutionalization of substantive global administrative norms in domestic settings. ${ }^{3}$. Demonstrating his wide-ranging expertise, Cassese positioned himself at the forefront of the scholarly debate on "legal globalization," arguing in 2005 that a "unitary cosmopolitan legal system is not on the horizon, nor is it perhaps among current ambitions"; rather, he envisaged a redevelopment of norms as legal orders evolve and coexist. His latest project builds on his predictions and seeks to understand the interactions, or as he terms it, collisions, among the legal orders encompassing the state, as well as those beyond it.

Cassese's two foundational observations-that legal orders are diverging, and that courts are players in shaping that movement-are neither novel nor original nor does Cassese claim them to be. Scholars have debated the fragmentation of international law in a variety of contexts. 4 Likewise, the importance of transnational quasi-judicial bodies to global governance has been widely recognized in international law and international relations scholarship. ${ }^{5}$ Cassese situates his understanding of fragmentation in the international relations' literature, arguing that the traditional meaning of "sovereign" is being diluted and that a concept of layered sovereignty is taking its place. The challenge, according to Cassese, is for the resultant pluralism to be sustainable. Cassese's contribution in this book is not his recognition of the dynamism of this movement but rather his seizure on the role of individual courts, and judges in particular, as critical actors in resolving new types of conflicts regulating the interaction of legal orders. ${ }^{6}$

This short book, originally given as lectures in Florence in 2008 at the Istituto di Scienze Umane and the Institute for Research on Public Administration, is divided into five chapters. In chapter one, Cassese

3. See, e.g., Sabino Cassese, The Globalization of Law, 37 N.Y.U. J. INT'L L. \& PoL. 973 (2006).

4. See generally, e.g., Eyal Benvenisti \& George W. Downs, The Empire's New Clothes: Political Economy and the Fragmentation of International Law, 60 STAN. L. REV. 595 (2007); Gerhard Hafner, Pros and Cons Ensuing from Fragmentation of International Law, 25 MICH. J. INT'L L. 849 (2004); Martti Koskenniemi \& Päivii Leino, Fragmentation of International Law? Postmodern Anxieties, 15 LEIDEN J. OF INT'L L. 553 (2002); Bruno Simma, Fragmentation in a Positive Light, 25 MiCH. J. INT'L L. 845, 846 (2004) (discussing how the question of fragmentation was taken up in 2000 by the United Nations' International Law Commission which produced "a feasibility study on the topic of 'risks ensuing from fragmentation of international law").

5. See, e.g., THE RULES, PRACTICE, AND JURISPRUDEnCE OF INTERNATIONAL CoURTS AND TRIBUNALS, supra note 1 .

6. Cassese describes, for example, how European state courts struggle to safeguard their identities with the growth of the European Union judicial presence and how international judicial bodies must interpret and apply national laws. SABINO CASSESE, WHEN LEGAL ORDERS COLLIDE: THE ROLE OF COURTS 21-22 (2010). 
outlines his assumptions and the basic premises of his analysis. $\mathrm{He}$ argues that law has replaced politics as the primary tool of interaction and influence in the international arena. He makes note of the proliferation of nonstate courts, though his focus is not on the overlapping jurisdictional puzzles that have evolved, a challenging development that he acknowledges. Rather, Cassese's project studies the contribution of judges to the establishment of a "connective tissue" among legal regimes. Citing the emergence of regional, supranational, and global institutions (his "legal orders") as the outputs of a pluralization of power, he claims that judges have replaced diplomats as the primary actors in governance. The concern, as he frames it, is to "ascertain[ whether they [judges] are succeeding in regulating the pluralization of public power and in contributing to the development of a common legal order." 7

Cassese moves from outlining the framework to providing illustrations of the convergences and divergences among the legal orders in chapter two. This chapter is divided into eight sections, six of which describe examples Cassese uses to explore how different legal orders coexist. The examples relate to a handful of substantive issues: energy production; environmental protection; sports regulation; human rights; agriculture and food production; justice and public order; freedom of expression; and disaster relief. They involve the intersection of seven global orders (the regulatory system of the Kyoto Protocol, the United Nations, the International Olympic Committee, the Food and Agricultural Organization, the World Bank, the International Monetary Fund, and the Internet Corporation for Assigned Names and Numbers), one supranational order (the European Community), and six national orders (Italy, China, the United States, Guatemala, Turkey, and Myanmar). In these examples, Cassese observes a lack of systemic or general rules capable of regulating the ways in which relations between the legal orders are "framed and balanced." 8

In chapter three, Cassese sets out to show how, in a world without general rules or first principles, quasi-judicial bodies enable legal orders to coexist. Here, Cassese draws upon the Swordfish dispute between the European Community and Chile in 2000-2001 and the Vlora dispute concerning the construction of a thermoelectric power plant in the Vlora Gulf on the Albanian coast between 2005 and 2007.9 Cassese employs these examples to demonstrate conflict among legal orders. In both cases, Cassese points out that the applicants sought to use the

7. Id. at 21 .

8. Id. at 43.

9. See id. at 49-53 (discussing the Swordfish dispute); id. at 53-58 (describing the Vlora case). 
fragmentation of state and extra state regulatory regimes to their advantage, appealing to those that best protected the applicants' interests. Most important is that the parties sought recourse in quasijudicial bodies. These disputes were not resolved by armed conflict or diplomacy. Neither executive nor legislative authorities were involved. Rather, the parties brought their conflicts to multiple adjudicatory bodies, reflecting also the complexities of their disputes that forced them to seek remedies in more than one institution. ${ }^{10}$

Although Cassese describes his own analysis as a review of the activities of the courts, his focus is undoubtedly on the role of individual judges-a unique perspective he offers from his personal experience. Chapter four studies the methods through which judges adjudicate conflicts among the orders. Throughout this exploration, Cassese sees judges as linking legal orders in the absence of general norms to regulate their relations. He disaggregates the role of the judge from the institution of the court and explores how individual judges shape and direct the course of the multi-jurisdictional orders. Cassese makes use of Alexander Hamilton's reference to the United States' judiciary as the "least dangerous branch" of the U.S. government to capture what Cassese perceives as the view of judges in transnational settings. ${ }^{11}$ Cassese asks whether judges are concerned only with the specific case before them or seek to establish general rules for coexistence among legal orders. He emphasizes the modalities of interpretation and elaboration employed by judges in their dispute resolution deliberations, addressing both vertical disputes (relations between national, supranational, and global legal orders) and horizontal disputes (relations between different global legal orders). In this chapter, Cassese highlights five groups of cases that he argues illustrate relations between legal orders: four show how legal orders interact in the vertical dimension, while the fifth shows interaction between two supranational legal orders-a horizontal relationship. He then seeks to identify "rules of coexistence" created and implemented by judges.

Certainly, transnational adjudication has deep and longstanding roots. Judges in border-spanning courts have been faced with competing and colliding legal orders throughout recent history. As other scholars have observed, the establishment of permanent buildings for regional and international courts signaled a move "to anchor the norms that the[ir] authorizing conventions and treaties seek to promote and

10. Cassese references commentary that, in the context of the Swordfish dispute, no adjudicatory body had jurisdiction or competence to resolve the entire scope of the parties' disagreement. See id. at 58 n.76.

11. Id. at 57 . 
enforce." ${ }^{12}$ Cassese addresses these norms, as well. He argues that in some cases norms establish the prevalence of one legal order over another; in other cases, they are limited to the establishment of a preference for one regulatory mechanism over another; in still others, they serve no useful purpose in regulating the dispute at all. Cassese maintains that judges retain the most power in these latter cases to develop relations across the orders in the absence of guiding norms.

The book ends with observations tying together the analyses of the preceding chapters. Cassese concludes on the basis of the examples he has selected, that the configuration of the relations between national and global legal orders is essentially judge-made. He outlines ways in which judges can and do regulate interactions among the orders, filling empty spaces and recognizing the primacy of "superior law."13 To be sure, he is not advocating that judges conspire or even communicate across orders on cases of transitive import; rather, he views their individual decisions as their contributions. The book approves of and supports the judicial development of a principle of primacy through which legal orders can interact-through "quasi-voluntary forms of cooperation."14 Thus, Cassese answers both the "who" and the "how" of the question he posited in 2005: judges alleviate the need for a system of different legal orders that would supersede the unstructured plurality.

Cassese's underlying presumptions deeply shape the direction of the book. While his concerns regarding fragmentation continue to be raised by some scholars, another chorus of voices contests Cassese's view, arguing that the legal orders have become more institutionalized and hierarchical than the fragmentation scholars imagine. ${ }^{15}$ Cassese places himself in the former camp, but advocates a single system and, in this book, locates the underpinnings of an adequate system in the work of the transnational judiciary. He assumes, without explanation, that regulation of pluralization is important and that judges should be the actors who do it. Cassese observes that judges have come to inhabit this role and makes claims to illustrate that observation but does not qualify his observations or evaluate whether judges are best positioned to take on such a task.

Further, Cassese's portrayal of the growth of the legal orders and their regulation by quasi-judicial bodies takes for granted that many of

12. JUDith RESNIK \& DenNis CURTIS, REPRESENTING JustiCE: INVENTION, CONTROVERSY, AND RIGHTS IN CITY-STATES AND DEMOCRATIC COURTROOMS 226 (2011).

13. CASSESE, supra note 6 , at 120 . Here and elsewhere in the book, the author notes the range of possible relationships across legal orders, settling on the idea that it may be necessary to adopt a "superior law" system.

14. Id. at 18.

15. See Simma, supra note 4 , at $845-48$. 
these quasi-judicial bodies are themselves built into or form part of those legal orders. Certain supranational legal orders, for example, have grounded their legitimacy in the creation of state-like apparatuses that include a judicial body to perform precisely the role to which Cassese refers. The dispute resolution body simultaneously adjudicates conflicts among colliding legal orders while its very existence is premised on the survival of one of them. ${ }^{16}$

With these presumptions in mind, the book would serve as a valuable seminar textbook, reflecting the lecture style through which the book was originally given. By presenting illustrations in which judicial or quasi-judicial bodies define the modalities of connection between different legal orders, Cassese teaches the reader with practical demonstrations - a refreshing change from the literature taking up similar themes from a theoretical perspective. At the same time, the selectivity inherent in limiting the group of examples leaves the reader at a loss for more and also leaves some important questions unanswered. Notwithstanding the many examples, the book does not make mention of what lessons the reader ought to take away from those examples. It notes their usefulness for the future, but never draws out their future applications and lacks details on what the judge-made order might create. While Cassese laments the pluralization of orders and argues for a single system, possibly judge-made and judge-directed, he never makes clear how that system would be different from the status quo or the recent past. What will this system provide beyond the coexistence that has taken shape? Is the singularity of the ideal system he envisions different from the aspirational order of international law grounded in a principle of primacy? Perhaps the precise contours, the justification for the superiority, as well as the implications of the judgemade system he has identified will become the subject of a future work.

For those interested in the trajectory of legal orders and their interaction, Cassese's book provides a useful and alluring collection of observations and one national judge's perspective on what that trajectory should look like. Those steeped in this field may notice his limited deployment of the conventional buzzwords of universality, solidarity, subsidiarity, and comity. Cassese does not address those terms or their imported meanings in too much detail, although his overall argument speaks to these themes. His rather benign, albeit bold, and narrow thesis, has far-reaching implications upon which he or other scholars may elaborate in forthcoming scholarship. The book gives an increased seriousness to the understanding of supranational and

16. It is worth mentioning, also, how Cassese relies on an understanding that the divergence and collision of the legal orders, contradictory concepts by definition, occur coincidentally. 
transnational institutions as constructs to be reckoned with. In Cassese's masterful view, judges will weave the web of relations among them and the national and international legal orders. 
